\title{
A face oculta da transferência de renda para jovens no Brasil
}

\author{
Marilia Pontes Sposito e Maria Carla Corrochano
}

Este artigo pretende analisar alguns dos pressupostos orientadores de programas sociais públicos destinados a jovens pobres no Brasil que envolvem transferência de renda e contemplam, em decorrência, a exigência de uma contrapartida que figura como obrigatória ${ }^{1}$. A escolha desse tipo de iniciativa decorre de algumas peculiaridades dessas ações, não obstante a diversidade de orientaçóes ou atores envolvidos, que oferecem novas questôes para análise no campo dos estudos sobre juventude. Esses programas buscam oferecer, diretamente aos segmentos juvenis que constituem o foco das ações, algum tipo de remuneração, em geral entendida como "bolsa", de duração variável, mas cujo sentido principal não residiria apenas no próprio benefício pecuniário - a renda que é transferida -, mas no conjunto de metas e ações previstas nessa concessão, configuradas, assim, na idéia de contrapartida.

1. As reflexões aqui esboçadas integram um campo amplo de investigações sobre açôes de governos municipais destinadas aos jovens em 75 cidades brasileiras de regiōes metropolitanas (Projeto Temático "Juventude, Escolarização e Poder local", com o apoio da Fapesp e do CNPq).

Os jovens e as políticas públicas

Nos últimos dez anos podem ser observadas sensíveis diferenças no debate público em torno do tema da juventude no Brasil. Não só emerge um novo interesse na investigação no âmbito das ciências humanas, como se espraiam iniciativas destinadas a esse segmento por parte dos mais diversos atores governamentais e da sociedade civil. No ano de 1995, em 
2. O Programa Pró-Jovem oferece condições de complementação da educação fundamental para jovens entre $18 \mathrm{e}$ 25 anos que não estejam vinculados ao mercado de trabalho formal. Com duração de um ano, o programa prevê uma bolsa e deverá ser executado em convênio com prefeituras de regiōes metropolitanas (cf. Novaes, 2005).

3. Cabe também ressaltar iniciativas recentes do Legislativo federal, que deu início ao processo de elaboração de um Plano Nacional de Juventude e do Estatuto da Juventude. diagnóstico sobre os jovens no Brasil, Rua afirmava que as políticas de juventude situavam-se no campo "do estado de coisas" e, assim, esse segmento não era objeto de ações específicas por parte dos governos, principalmente no nível federal (cf. Rua, 1998). Mas nesse momento já era reconhecida uma sensível atuação no âmbito de organizações não-govermentais que se dedicavam ao trabalho com jovens, sobretudo no campo da cultura, apesar de sua fragmentação e descontinuidade (cf. Castro e Abramovay, 1998; Sola, 1998).

No plano federal, a gestão Fernando Henrique Cardoso (1995-2002) marcou uma inflexão importante por meio de iniciativas originadas em diversos ministérios, mas sem articular essas açôes no intuito de constituir um campo de políticas públicas para os jovens (cf. Sposito e Carrano, 2003; Castro e Abramovay, 2003). No final de seu mandato, e no período de transição para o novo governo, a visibilidade do tema ampliou-se ainda mais com um intenso debate empreendido sobretudo por organizações da sociedade civil que tinham como alvo o trabalho com os jovens.

O governo federal empossado em 2003 também reconheceu a importância da temática ao constituir um grupo interministerial para a discussão das políticas de juventude, destinado a formular um conjunto de diretrizes de ação (cf. Novaes, 2005). Algumas iniciativas foram observadas no início do mandato, como o Programa Primeiro Emprego e, mais recentemente, a criação do Programa Pró-Jovem², ao lado da instituição da Secretaria Nacional de Juventude e do Conselho Nacional de Juventude ${ }^{3}$.

Nesse mesmo período, na esfera do Executivo municipal, principalmente em administrações de centro-esquerda a partir de 1997, começaram a ser implantadas açôes que propunham inclusive novos desenhos institucionais, como expressão de duas orientaçôes: uma melhor articulação de iniciativas, que em geral permaneciam isoladas, e uma proposta de aproximação do executivo municipal para os jovens moradores das cidades por meio da criação de novos canais de interlocução (cf. Sposito e Carrano, 2003; Sposito, 2003).

O teor e o impacto dessas iniciativas - federais e municipais - são variados em todo o país e não refletem, necessariamente, mudanças significativas no interior de uma agenda pública que tem a juventude e seus direitos como tema. Sinalizam, no entanto, inflexões importantes que podem constituir novas arenas no âmbito da esfera pública, como lócus de disputa em torno dos modelos normativos que orientam as representaçôes sobre a con- 
dição juvenil no país, bem como as expectativas de sua inserção no mundo adulto ${ }^{4}$.

Por outro lado, a própria unanimidade em torno do caráter legítimo de um novo campo de ações no âmbito das políticas públicas especialmente voltadas para jovens não é real, indicando a existência de uma série de conflitos subjacentes à sua constituição que nem sempre são evidentes. A rigor, a visibilidade do tema tem privilegiado elementos de consenso que não deveriam obscurecer os possíveis litígios.

Um foco mais visível de dissenso reside na disputa de recursos escassos destinados às políticas sociais, ampliando cada vez mais o escopo das demandas e das necessidades de novos investimentos, ao incluir novas modalidades de público a que se destinam as ações. Essa situação atravessa as várias instâncias da federação - federal, estadual e municipal - como também percorre o interior dos governos, ocorrendo maior disputa por verbas ou recursos para assegurar ações que muitas vezes são superpostas e não nascem de uma estratégia clara de formulação de políticas (cf. Rua, 1998). No entanto, a obtenção de verbas em regime de escassez não constitui o tópico mais relevante para a compreensão dos elementos que estão em jogo nessa disputa.

Sob o ponto de vista dos objetivos da análise a ser empreendida neste artigo, é preciso reconhecer que ocorre, principalmente, um conflito em torno das orientaçôes que alimentam as ações destinadas aos segmentos juvenis, incluindo nesse campo um conjunto de representaçôes que no limite pode até se opor a qualquer tipo de intervenção específica destinada aos jovens ${ }^{5}$.

No campo das orientaçôes, um primeiro eixo de conflitos diz respeito à própria necessidade das políticas específicas para a juventude: as demandas dos jovens não estariam necessariamente contempladas no acesso às políticas universais como saúde, educação, transporte, esporte, entre outras? Para um campo importante de atores, os jovens teriam satisfeitas suas principais demandas no âmbito dessas políticas setoriais, sendo desnecessário qualquer recorte que os privilegiasse como destinatários específicos de ações públicas ou governamentais. No outro extremo estariam radicadas as posições que defenderiam as políticas da juventude apenas como ações com clara focalização, sendo nesse caso destinadas apenas aos jovens em "situação de exclusão social" ou em condições de "vulnerabilidade".

Um segundo eixo reside na falta de consenso em torno da própria definição do que seriam políticas públicas de juventude. Para alguns autores latino-americanos (cf. Bango, 2003; Dávila, 2003), as políticas de
4. Não se pretende definir neste momento o conceito de juventude. Trata-se não apenas de reiterar o caráter histórico e cultural da condição juvenil, mas de pressupor que os modelos simbólicos que tendem a compor uma imagem do que devem ser os jovens em uma determinada sociedade, além de normatizar sobre o trânsito para uma condição adulta considerada desejável, delimitam aquilo que pode ser reconhecido como o comportamento legítimo para o próprio momento do ciclo de vida. Apesar da diversidade de modelos, é possível considerar que algumas formas constituem dominância e passam a orientar a experiência concreta dos jovens, mas adaptadas às peculiaridades que decorrem de classe social, sexo, etnia, extração religiosa, condição de vida urbana ou rural.

5. Neste artigo, o sentido dado à noção de representação se apóia sobretudo em Henri Lefebvre, que recusa a dicotomia entre o que está fora e é exterior (como coisa) e as representaçôes que também vêm de dentro e são contempo- 
râneas à constituição do sujeito, tanto na história de cada indivíduo como na gênese do individual na escala social. Desse modo, as representaçôes "não são nem falsas nem verdadeiras, mas ao mesmo tempo falsas e verdadeiras: verdadeiras como respostas a problemas 'reais' e falsas na medida em que dissimulam objetivos 'reais'" (Lefebvre, 1980, p. 55).

6. Os regimes de cidadania definem um conjunto de direitos e traçam os limites da intervenção do político na sociedade. Para a autora, os jovens seriam um público prioritário em direção aos regimes da cidadania que poderiam ser compreendidos, cada um, como conjunto hierarquizado de status: "Ao lado do cidadão normal aparecem os grupos com estatuto de 'minorias', tanto no domínio dos direitos cívicos como no dos direitos sociais" (Loncle-Moriceau, 2001, p. 87). Os regimes da cidadania caminhariam no sentido da diferenciação das ações, restando sempre o desafio de sua universalização. juventude não estariam inscritas nas políticas setoriais, mas diriam respeito necessariamente a outros níveis de ação que não incidiriam sobre o objeto das grandes políticas: saúde, trabalho, habitação e educação. Estariam mais próximas, assim, de áreas articuladas às demandas culturais, de tempo livre, de lazer e, principalmente, de açôes que possibilitassem a real participação dos jovens, ampliando a esfera de sua cidadania. Ernesto Rodríguez propõe, em suas análises, que as próprias demandas dos jovens em direção às políticas estariam restritas ao campo simbólico e expressivo (cf. Rodríguez, 2001).

Esses dois primeiros eixos de conflito remetem a algumas questôes importantes em torno das intervenções públicas dos governos, em vários países, privilegiando uma ação específica voltada para a juventude. Tem sido crescente a ação governamental destinada aos jovens tanto na América Latina como em vários países europeus, mas é preciso reconhecer que essas políticas aparecem como um "objeto difuso quando comparado com os domínios mais consolidados a partir de estruturas ministeriais portadoras de competências delimitadas de intervenção", conforme análise de Loncle a partir da realidade francesa $(2003$, p. 24).

Assim, desde suas origens, as políticas de juventude constituem um espaço de intervenção pública transversal e periférico (cf. Idem, p. 25). Se considerarmos a experiência francesa, mais antiga nesse domínio, poderíamos dizer que as políticas de juventude dificilmente seriam originadas da lógica setorial. A principal razão para esse fato reside na dificuldade de constituição de uma intervenção pública a partir de uma categorização em termos de idade. Para Loncle, duas outras razões também interferem nessa dificuldade: a primeira remete à forte dimensão simbólica das políticas de juventude, pois em geral não estão munidas de um fundamento autônomo e, assim, em períodos de crise, poderiam desaparecer como problema público; a segunda deriva de sua "natureza" transversal, ou seja, ao terem a "integração dos jovens na sociedade" como missão, elas dizem respeito, potencialmente, a quase todas as açôes do Estado (cf. Idem, p. 27).

De certo modo, a experiência histórica indica que orientaçôes explícitas voltadas para a juventude exigem a aceitação do pressuposto da transversalidade, mas também a adoção de uma lógica que transcenda a ação setorial, sendo capaz, de alguma forma, de assumir a perspectiva da idade nas suas orientações. Esse tipo de prática constituiria uma ampliação nas concepções dos direitos da cidadania, introduzindo a idéia dos "regimes de cidadania" tal como registra Loncle-Moriceau $(2001)^{6}$. 
No Brasil, torna-se extremamente complexa a adoção de perspectivas que definem as demandas juvenis apenas no universo simbólico ou expressivo, mesmo que se reconheça sua fragilidade como grupo de pressão no âmbito da esfera pública. Pesquisas recentes confirmam que necessidades e expectativas explicitadas pelos jovens não se limitam ao campo da cultura, mas incidem sobre melhores condições de acesso ao mundo do trabalho, à educação e ao transporte, entre outras ${ }^{7}$ (cf. Sposito, 2005; Guimarães, 2005) .

A proposta de constituição de transversalidade nas ações públicas parece articular as demandas dos jovens no âmbito das "grandes políticas", sendo nelas introduzidas não apenas a perspectiva de gênero, ou de etnias, mas o reconhecimento das especificidades dos momentos experimentados ao longo do ciclo de vida. No entanto, essas orientações também não seriam impeditivas da abertura de novas modalidades de ação pública, especialmente destinadas aos jovens.

Um terceiro eixo de conflito reside no tipo de institucionalidade mais apropriado à ação, nas diversas esferas do Poder Executivo. Os debates ocorridos antes das eleiçôes presidenciais, em 2002, e nos dois primeiros anos do governo Lula absorveram a experiência dos países latino-americanos ao evitar a criação precipitada de organismos que, sem nenhuma legitimidade no interior da máquina governamental, constituiriam agenciamentos sobretudo burocráticos, sem poder de impacto na formulação, integração e acompanhamento das ações ${ }^{9}$. No interior do Poder Executivo municipal, organismos específicos - como as assessorias, coordenadorias e secretarias de juventude - constituem um leque diferenciado de atribuições e de graus de reconhecimento externo ou no interior da máquina governamental, sendo muito difícil qualquer generalização sobre os possíveis benefícios de sua criação.

No terreno das representações dominantes sobre os jovens, ocorre certo lastro comum que esteve presente no nascimento das ações. Grande parte delas operou com a imagem de uma juventude perigosa, potencialmente violenta, que necessitava de uma ampla intervenção da sociedade para assegurar seu trânsito para a vida adulta de modo não ameaçador a certas orientações dominantes. Por essas razões, o grande tema que ocupa a constituição de uma opinião pública em torno dos jovens no Brasil sempre teve suas origens na violência, sobretudo nos centros urbanos. A temática do desemprego, fortalecida no fim da década de 1990, não rompe de modo fundamental com o campo simbólico anterior, aparecendo como um problema
7. Um dos maiores campos de conflitos entre jovens e poder municipal, nos últimos dois anos, em várias cidades brasileiras, reside no setor de transportes públicos e no preço das tarifas praticadas, consideradas abusivas pelos segmentos juvenis.

8. A pesquisa conduzida pelo Instituto da Cidadania revela múltiplos aspectos que mobilizam os jovens, sobretudo na esfera do trabalho e da escola, mas que atingem o âmbito dos principais problemas sociais identificados, entre eles o tema da segurança e as expectativas de acesso aos bens culturais (cf. Abramo e Branco, 2005).

9. A criação de um Instituto Nacional de Juventude foi uma das propostas até o momento não implementadas em virtude de dificuldades observadas na experiência da América Latina. 
10. A designação utilizada - jovens pobres - é intencional, uma vez que não se pretende aceitar alguns adjetivos que vêm sendo adotados, como "excluídos, vulneráveis, em situação de risco ou miseráveis". social por levar os jovens a uma ociosidade forçada, propiciadora de um tempo livre perigoso, que os aproximaria, inevitavelmente, das condutas criminosas, sobretudo aquelas ligadas ao tráfico de drogas ilícitas (cf. Corrochano e Gouvêa, 2003). Felicia Madeira, ao analisar programas voltados para o emprego juvenil, observa que as iniciativas são marcadas pelos debates conjunturais em torno do tema da violência juvenil, com forte presença midiática, e a proposta pública aparece como um antídoto a ser utilizado como proteção contra o contágio da violência (cf. Madeira, 2004).

É preciso reconhecer que as políticas de juventude são normativas: prescrevem ou enfatizam normas, significados ou conteúdos simbólicos que incidem sobre expectativas de disseminação de condutas juvenis consideradas adequadas para um determinado tempo e espaço. Para Loncle, ao analisar cem anos de políticas de juventude na França, as iniciativas sempre decorreram de um tripé assentado na idéia de cidadania, de proteção e de pacificação social. A idéia de cidadania prevalecente nessas iniciativas estaria principalmente radicada na "obrigação de cidadania", ou seja, tratase de transformar os jovens em cidadãos ativos, em indivíduos que participam da sociedade nacional, dispostos a defendê-la em tempo de guerra ou renová-la em tempo de paz. Assim, os registros que assinalam as relações sociais que ancoram as ações públicas estariam dominados por conteúdos simbólicos que permitiriam principalmente "identificar os projetos globais do Estado" e com maior fragilidade resolver efetivamente os problemas dos jovens (cf. Loncle, 2003, p. 15).

Tendo em vista a diversidade de orientações no Brasil, transformadas em campo de disputa simbólica nos mais variados escalóes do aparelho estatal e dos atores da sociedade civil, incluindo nesse campo os próprios segmentos juvenis em sua diversidade, é preciso considerar no plano da análise as tensōes e as ambigüidades que marcam as orientaçôes e os programas. Se acrescentarmos às questôes de ordem conceitual as dificuldades de mapeamento de açôes e orientações que ainda constituem um campo extremamente recente, alguns recortes se fazem necessários.

\section{A constituição de um modelo de ação para jovens pobres ${ }^{10}$}

As iniciativas que envolvem algum tipo de transferência de renda oferecem problemáticas relevantes para a análise do estatuto simbólico e político que a questão juvenil alcança no país. A primeira diz respeito a um campo novo de inserção profissional possibilitada pelas demandas que sua imple- 
mentação encerra, ou seja, a necessidade de envolver novos profissionais, ainda não submetidos a um perfil técnico definido, que passam a desenvolver atividades, sendo designados como estagiários, animadores culturais, educadores sociais ou oficineiros. São modos de recrutamento vinculados às atividades de estágio e prestação de serviços, bastante marcados por certa informalidade, que em sua grande maioria atraem jovens, muitos de origem popular e que conseguiram prosseguir em seus estudos e ingressar no ensino superior sem emprego definido, ou que apresentam uma história de engajamento em açôes coletivas de natureza sociocultural em seus bairros. Essa situação pode ser encontrada tanto nos organismos municipais, que se transformam em agentes recrutadores desse tipo de força de trabalho ou funcionam apenas como responsáveis pelos recursos financeiros, como no interior de organizações não governamentais, associações ou fundaçōes parceiras na execução de projetos, que, por meio do acesso a verbas públicas, tornam-se responsáveis por sua contratação. Esse é um aspecto pouco estudado, pois parece estar criando alternativas de ocupação para setores mais escolarizados, tanto de segmentos médios como populares, que desenvolveriam açôes cujo alvo seria também os jovens, porém aqueles mais prejudicados pelos processos de exclusão ${ }^{11}$.

Uma segunda problemática também merece ser examinada, ao se eleger como eixo para a análise os jovens usuários dessas ações que asseguram algum tipo de auxílio pecuniário. Em meio à diversidade de orientaçôes prevalecentes, seus impactos permanecem em grande medida desconhecidos, tanto na sua concepção como nos modos de implantação a partir de uma base conceitual comum. Não se trata de tecer considerações que incidam sobre o tema de sua avaliação, uma vez que parte das iniciativas constitui seus próprios mecanismos para isso, devendo o tema ser mais bem equacionado no âmbito dos estudos sobre políticas públicas nas ciências sociais (cf. Madeira, 2004). Busca-se esboçar alguns recortes analíticos em torno dos formatos que constituem essas iniciativas, que, não obstante a diversidade de orientações, de formas de execução ou de atores responsáveis, sinalizam alguns aspectos comuns que tendem a configurar uma realidade nova e bastante desafiadora.

As iniciativas mais visíveis tiveram início no âmbito federal, no segundo mandato do governo $\mathrm{FHC}$, e se disseminaram em várias cidades ${ }^{12}$; outras nasceram no Executivo municipal. Entre as ações arroladas, três foram selecionadas para a análise dessa problemática, apenas como exemplos: o Projeto Agente Jovem de Desenvolvimento Social e Humano e o Serviço Civil
11. Para Dubet (2004), esse tipo de ação também pode ser interpretado como uma dificuldade cada vez maior dos adultos de cumprirem sua tarefa educativa, o que acabaria por dificultar o processo de construção da identidade entre os próprios jovens.

12. Neste artigo serão examinadas apenas as iniciativas públicas, implantadas por meio de parcerias com associações da sociedade civil (ONGs, fundações empresarias, entre outras). 
13. Doravante chamados, respectivamente, Projeto Agente Jovem, SCV e PBT Renda.
Voluntário (SCV), ambos iniciados no final dos anos de 1990 no âmbito federal, e o Programa Bolsa Trabalho Renda da cidade de São Paulo (2001$2004)^{13}$. São programas empreendidos tanto pelo Poder Federal como pelo Municipal, que exigiram parcerias para sua implementação; foram constituídos a partir de pressupostos diversos, mas, curiosamente, apresentaram algumas importantes semelhanças no modo de ação, sendo por essas razões utilizados como exemplos. Por outro lado, essas propostas foram selecionadas também em função de sua abrangência geográfica e do escopo das atividades realizadas, pois dizem respeito a experiências nacionais que até o momento atingiram aproximadamente mais de 100 mil jovens e a um programa já encerrado do governo de um grande município, a cidade de São Paulo, que atingiu em torno de 50 mil jovens.

\section{Projeto Agente Jovem de Desenvolvimento Social e Humano}

Criado em 2000, no âmbito da Secretaria de Estado de Assistência Social (cf. MPAS, 2001a), vinculou-se ao Plano Nacional de Segurança Pública, mais especificamente a um de seus compromissos, relacionado à intensificação das ações de prevenção do fenômeno da violência inserido no Programa Nacional de Direitos Humanos. O projeto atingiu $110 \mathrm{mil}$ jovens no governo FHC e, embora planeje superar os índices de atendimento do governo anterior, até julho de 2005 o governo atual havia atendido 57.038 jovens. Atualmente, o projeto não está mais vinculado à área da segurança pública, sendo de responsabilidade do Ministério do Desenvolvimento Social e de Combate à Fome (cf. MDS, 2005a), mas sem alterações significativas nos objetivos ou no público-alvo.

Em sua implementação, as três esferas de governo - federal, estadual e municipal - são envolvidas. Enquanto as duas primeiras se responsabilizam pela concepção, monitoramento, assessoria e avaliação, a esfera municipal realiza a execução, diretamente ou por meio de parcerias com universidades ou organizações não-governamentais. A garantia dos recursos é de responsabilidade do governo federal, contando com a participação das duas outras esferas e de parcerias com a iniciativa privada (cf. MPAS, 2001b).

O público-alvo são os jovens com idade entre 15 e 17 anos, prioritariamente aqueles que estejam fora da escola, participem ou tenham participado de outros programas sociais do governo, estejam em situação de vulnerabilidade e risco pessoal e social, egressos ou sob medida socioeducativa, oriundos de programas de atendimento à exploração sexual e comercial de 
menores. Adolescentes portadores de algum tipo de deficiência têm direito a $10 \%$ das vagas (cf. MDS, 2005a). Anteriormente, esse público era escolhido pelos próprios municípios ou organizações responsáveis pelo projeto, podendo dar lugar a diferentes formas de clientelismo. $\mathrm{Na}$ gestão atual, embora o problema persista ${ }^{14}$, foram implementadas modificaçôes no processo de seleção dos jovens a partir da introdução do Cadastro Úni$\mathrm{Co}^{15}$, respondendo a critérios de renda.

No momento de sua formulação, o projeto estabelecia como desafio a construção de uma proposta dirigida a determinado segmento juvenil que, sem ter idade adequada para ingressar no mercado de trabalho e para o qual havia reconhecida escassez de programas, estaria conseqüentemente mais exposto à "marginalidade" (MPAS, 2001b) ${ }^{16}$.

Depreende-se dessa formulação a necessidade de construir um programa que pudesse "ocupar" esses jovens, retirando-os da situação de "risco" em que se encontravam. Seus objetivos específicos permanecem os mesmos desde sua regulamentação ${ }^{17}$ : criar condições para inserção, reinserção e permanência do jovem no sistema de ensino; promover sua integração à família, à comunidade e à sociedade; prepará-lo para atuar como agente de transformação e desenvolvimento de sua comunidade; contribuir para a diminuição dos índices de violência, uso de drogas, DSTs e gravidez não planejada; e desenvolver ações que facilitem sua integração e interação quando estiver inserido no mundo do trabalho (cf. MDS, 2005a).

No começo por um período de seis meses e a partir de 2001 por um período de até doze meses, os jovens, além de continuar na escola ou retornar a ela, devem freqüentar cursos de capacitação (seis meses) e implementar projetos de intervenção em suas comunidades (seis meses), prioritariamente nas áreas de saúde, cultura, meio ambiente, cidadania, esporte e turismo. Durante todo o período, recebem bolsa mensal no valor de $\mathrm{R} \$$ $65,00^{18}$ e são acompanhados por "instrutores" - profissionais de diferentes áreas que ministram aulas - e "orientadores sociais" - preferencialmente estudantes universitários - que devem possuir experiência de trabalho com jovens, responsabilizando-se por facilitar a ação social juvenil.

Seguindo essa breve descrição, emergem duas representações em torno dos jovens: fonte e vítima de problemas sociais e, ao mesmo tempo, "protagonista" do desenvolvimento de sua "comunidade". Quanto à primeira imagem, trata-se de pensar projetos para aqueles considerados pouco integrados socialmente, sobretudo nas instituições mais tradicionais (família e escola), e por isso fortemente sujeitos ao risco social na perspectiva do
14.Em avaliação recente realizada pelo próprio MDS, um dos municípios declarou pressão de alguns prefeitos para a indicação de nomes para o projeto (cf. MDS, 2005b).

15. Sobre o novo modo de cadastramento no Programa Agente Jovem, ver CEF (2005).

16. "Os jovens de 15 a 17 anos, em localidades empobrecidas (municípios/comunidades), não dispõem de grandes alternativas. Além disso, os diversos programas e projetos de atendimento ofertados não suprem as necessidades dessa faixa, que ainda não tem idade suficiente para entrar no mercado de trabalho, ficando à margem, sujeita à ociosidade e à marginalidade" (MPAS, 2001b).

17. Portaria n. 879, publicada em dezembro de 2001 (cf. MPAS 2001a).

18. O valor fixado no início do programa permanece o mesmo. 
projeto. Ao mesmo tempo, impóe-se uma tarefa ao jovem: uma vez adequadamente formado - em um período bastante breve e sem muitas alterações no ambiente em que vive -, ele pode e deve ser estimulado a contribuir para a melhoria das condiçôes de vida de sua comunidade a partir de uma determinada intervenção social para a qual será orientado.

Embora nesses fragmentos se reconheça certo potencial juvenil, são visíveis seus limites: primeiramente, a ênfase em certos aspectos comportamentais - como se todo e qualquer jovem em qualquer momento histórico e social fosse naturalmente predisposto a provocar mudanças -; em segundo lugar, essa mudança será realizada apenas se o mundo adulto reconhecer e criar condiçôes para isso, de onde se pode subentender a dificuldade do jovem em fazer-se ouvir e em agir por si só. Por fim, atribui ao jovem uma tarefa dificílima - a de transformar a sua "comunidade", em geral desprovida de equipamentos públicos e serviços que assegurem um mínimo de qualidade de vida. $\mathrm{O}$ envolvimento em ações e capacitações voltadas para a "comunidade" ao lado da continuidade da trajetória escolar são as contrapartidas exigidas pelo recebimento da bolsa. De certo modo, espera-se que as capacitações também permitam ao jovem a preparação para algum tipo de inserção futura no mercado de trabalho. Ora, nem o número de horas destinadas às capacitações, nem o perfil dos profissionais que atuam junto aos jovens parecem garantir essa possibilidade. Avaliação realizada pelo Tribunal de Contas da União em trezentos municípios, no ano de 2004 (cf. TCU, 2004), aponta o perfil dos chamados instrutores e orientadores sociais como um dos aspectos mais frágeis do projeto - em apenas 19\% dos casos a equipe técnica tinha perfil adequado.

Além disso, seguindo essa avaliação, em muitos municípios os jovens estavam desempenhando tarefas que em pouco ou nada condiziam com os objetivos do projeto, como serviços de limpeza e datilografia, entre outros. A despeito dos benefícios percebidos em termos de desenvolvimento pessoal, social e comunitário dos agentes, a falta de continuidade é apontada como um dos entraves para que o projeto cumpra seus objetivos de inclusão social. Nesse sentido, algumas das principais recomendaçôes do TCU (2004) relacionavam-se à necessidade, além do monitoramento, de articulação com o Programa Nacional de Primeiro Emprego e outras iniciativas de geração de trabalho e renda. Avaliação mais recente realizada pelo próprio MDS também constatou os limites da maioria dos municípios em relação a esses aspectos, mas não apresentou nenhuma proposta para sua superação (cf. MDS, 2005b). 
De caráter qualitativo, estudo realizado por Camacho (2004) observou uma forte tensão entre equipes técnicas e jovens, sobretudo em relação à situação e à condição juvenil. Ora as equipes técnicas viam os jovens quase como crianças, incapazes de assumir responsabilidades (como declara uma das jovens), instalando entre eles certa "moratória social", ora como adultos, quando lhes eram exigidas "condutas adequadas como agente jovem" (Camacho, 2004).

A continuidade do projeto na gestão federal pode acenar ao menos como uma tentativa de não interromper açôes sem justificativa alguma no âmbito público. Mas sua manutenção, sem nenhuma mudança, ao lado da criação de novos programas para jovens, revela ainda a precariedade na absorção das avaliações e a eventual fragmentação das ações voltadas para a juventude.

\section{Programa Serviço Civil Voluntário}

No âmbito do Programa Nacional de Direitos Humanos, o Programa Serviço Civil Voluntário foi criado em 1996 e iniciou suas atividades no ano de 1998, em caráter experimental, nos estados do Rio de Janeiro e do Distrito Federal. Resultado da ação integrada dos anteriores Ministério da Justiça/ Secretaria de Estado dos Direitos Humanos e Ministério do Trabalho/Secretaria de Políticas Públicas e Emprego, foi inicialmente implementado de forma descentralizada por intermédio dos Planos Estaduais de Qualificação (PEQS) e de parcerias com entidades da sociedade civil. Desse modo, os responsáveis pela execução das ações eram entidades de capacitação (ONGs, Sistema $S$, sindicatos e universidades) contratadas pelas secretarias estaduais de Trabalho ${ }^{19}$.

No governo atual, o SCV encontra-se alocado no Ministério do Trabalho e Emprego, como um dos projetos do Programa Nacional de Primeiro Emprego. Se uma parte de seus objetivos se modificou, seu formato permanece idêntico.

Em sua concepção original, priorizava-se a atenção a moças e rapazes na faixa dos 18 anos excluídos e dispensados do serviço militar obrigatório, embora alguns estudos avaliem que essas características parecem ter sido abandonadas aos poucos (cf. Leão, 2004). No atual governo, a menção ao serviço militar desapareceu completamente, corroborando tendência observada na gestão anterior; a faixa etária ampliou-se e jovens com Ensino Fundamental completo e Ensino Médio incompleto também podem par-
19. Os recursos advinham do FAT - Fundo de Amparo ao Trabalhador, por meio do extinto Planfor (cf. Ministério da Justiça, 2000).

novembro 2005 151 
ticipar. Os atuais requisitos são: idade entre 16 e 24 anos, renda familiar baixa (menos de meio salário mínimo por pessoa), situação de desemprego, não freqüência à escola e escolaridade inferior ao Ensino Médio. Negros e pardos, portadores de deficiência e filhos de famílias chefiadas por mulheres devem ser priorizados no momento da seleção, realizada pelas entidades executoras do programa, à semelhança do Projeto Agente Jovem em suas fases iniciais (cf. MTE, 2005).

Inicialmente, o programa apresentava-se como um "rito de passagem" da juventude à idade adulta, enfatizando prioritariamente dois aspectos: $\mathrm{o}$ "despertar" do jovem para a "cidadania" - compreendida como solidariedade social e desenvolvimento de ações concretas na comunidade - e a preparação para o ingresso no mundo do trabalho. Mais especificamente, estabelecia como objetivos no trabalho com moças e rapazes a elevação da escolaridade, o desenvolvimento dos valores de cidadania, participação, a solidariedade, a não-discriminação, o respeito à diversidade social e ao meio ambiente, a qualificação e o encaminhamento para oportunidades concretas de trabalho e geração de renda. Atualmente, o fato de ser parte do Programa Nacional de Primeiro Emprego deixa mais clara a intenção de contribuir para a inserção do jovem, inclusive exigindo das entidades executoras a incorporação de $20 \%$ deles no mercado formal de trabalho. Mas permanecem os objetivos de elevação da escolaridade, formação para a cidadania e prestação de serviços comunitários. Novamente, aqui, a contrapartida para o recebimento da bolsa é a realização de cursos complementares e "serviços comunitários".

Todos esses objetivos devem ser cumpridos ao longo de seis meses, com uma carga horária total de seiscentas horas, abarcando três atividades fundamentais: elevação da escolaridade (trezentas horas), qualificação profissional (cem horas) e formação em direitos humanos e cidadania (duzentas horas), incluindo a prestação de serviços comunitários a partir da realização de campanhas e serviços sociais, entre outras. O valor da bolsa foi alterado, de $\mathrm{R} \$$ 100,00 no final do governo anterior, para $\mathrm{R} \$ 150,00$ no governo atual.

Até o ano de 2002, o programa havia sido implementado nas 27 unida-

20.Não foi possível obter os números no atual governo. des federativas, tendo beneficiado aproximadamente 47 mil jovens, com investimento aproximado de $\mathrm{R} \$ 47,2$ milhôes $^{20}$. Desde o ano de criação do programa, a anterior Secretaria Nacional de Políticas Públicas de Emprego (gestões 1995-1998 e 1999-2002) realizou três avaliações mais aprofundadas, nas quais foram levantados problemas e dificuldades, além de aspectos positivos e inovadores. A última avaliação, realizada em 2001 
por universidades públicas e organismos de pesquisa a partir de 27 estudos de casos, apresenta algumas informaçôes sugestivas, com ênfase em critérios de "eficiência" e "eficácia" das ações.

De maneira geral, o estudo revelou índices elevados de eficiência e eficácia - em torno de $90 \%$ a $95 \%$ no cumprimento das metas -, chegando até mesmo a enfatizar o potencial do programa como política de juventude: "O SCV 'parece' caro em face de sua duração (média superior a oitocentas horas, recomendando-se no mínimo seiscentas). Mas é, sem dúvida, muito mais barato que qualquer outra alternativa de contenção ou repressão de jovens - sem falar nos benefícios registrados pelos treinandos" (Secretaria Nacional de Políticas Públicas de Emprego, 2002, p. 19). De qualquer modo, aqui novamente emerge um distanciamento da perspectiva dos direitos. Por esse estudo, o programa é avaliado como bom principalmente porque ocupa os jovens, dificultando seu envolvimento com o mundo do crime. Os possíveis benefícios registrados pelos "treinandos" ganham lugar secundário. Mas, apesar desse "otimismo", a avaliação também apresentou algumas dificuldades do programa em garantir 50\% das vagas para mulheres, a inclusão de pessoas portadoras de deficiência, parcerias para o encaminhamento ao mercado de trabalho e a aplicação de recursos adicionais ao antigo FAT.

Do ponto de vista dos benefícios para os jovens, a pesquisa revela que, em média, 95\% dos casos apresentam efeitos positivos, sobretudo em relação aos seguintes aspectos: incentivo à qualificação para o trabalho, maior participação/integração na comunidade, melhoria das relações sociais e familiares, estímulo a retornar ou concluir os estudos. Mas, ao mesmo tempo, também foram observados índices baixos no que se relaciona à qualificação para o mundo do trabalho, à continuidade e posterior inserção no mercado e à elevação da escolaridade.

Nesse sentido, a própria avaliação recomenda a integração com outros programas, que reforcem a qualificação e ampliem as chances de inserção profissional dos jovens, além da busca efetiva de garantia da retomada ou prosseguimento dos estudos em nível básico para 100\% dos inscritos. Ou seja, a avaliação evidencia claramente que os impactos do programa quanto à inserção do jovem no mundo do trabalho e da escola estão aquém do esperado.

Conclusão semelhante quanto a esse último aspecto também foi obtida em pesquisa realizada por Leão (2004) com egressos de duas turmas do programa na região metropolitana de Belo Horizonte ${ }^{21}$. Em análise mais apro-
21. Leão (2004) pesquisou o desenvolvimento do Programa SCV em duas turmas da RMBH, durante o ano de 2002, por meio de entrevistas semidiretivas com os coordenadores do programa, observações de campo, questionário para 57 jovens e treze entrevistas semi-estruturadas com egressos. 
fundada, esse autor enfatiza o predomínio daquilo que nomeia como "pedagogia da precariedade". Observando os espaços, ouvindo jovens, educadores e coordenadores do programa, conclui que os cursos oferecidos eram tomados pelos educadores como dádivas para uma juventude empobrecida, vivendo em situação de risco social. Salas pouco adequadas, falta de material, ausências freqüentes dos educadores, excesso de aulas de formação geral em detrimento das de qualificação profissional - o que era tomado pelos jovens como "enrolação" -, entre outros aspectos, eram evidências de situações marcadas pela precariedade, revelando uma determinada lógica, segundo o autor, de que para "pobre qualquer coisa parece bastar".

A bolsa oferecida aos jovens mediante a freqüência aos cursos e o desenvolvimento de algum tipo de trabalho comunitário também acabava por transformar-se em objeto de muitas polêmicas. Ainda segundo Leão, na medida em que os jovens se frustravam com os cursos, canalizavam sua permanência no programa particularmente em função da bolsa, do vale transporte, do lanche, ou seja, dos benefícios recebidos (cf. Leão, 2004, p. 246). Ao mesmo tempo, sem atentar para a própria precariedade das atividades oferecidas, educadores e coordenadores acabavam por alegar que os jovens só desejavam a bolsa, o que os levou à criação de inúmeros mecanismos para controlar seu uso e os critérios de recebimento.

Além desses, outros desencontros são revelados por Leão: vários jovens desejavam ingressar no mercado formal de trabalho, enquanto os cursos estavam voltados para a formação para ocupações autônomas; as expectativas de realização de estágios eram frustradas, pois era assegurado um total de apenas vinte horas e, quando uma oportunidade melhor aparecia, eram favorecidos os jovens mais "comportados". Em relação à auto-estima, enquanto educadores e coordenadores enfatizavam a sua elevação como um resultado importante do projeto, os jovens não se percebiam como portadores de baixa auto-estima e não estavam preocupados com esse tema, o que revela mais um descompasso entre os jovens e o corpo de educadores ou técnicos, sinalizador das dificuldades de interaçáo.

A realização do trabalho comunitário no caso estudado por Leão foi dificultada por problemas de organização e funcionamento das turmas, mas também pela desconsideração em relação aos desejos e aos interesses dos jovens e das comunidades.

Seguindo tendência já observada no Projeto Agente Jovem, o novo formato deste programa manteve-se praticamente inalterado. Em relação ao compromisso das entidades responsáveis pela inserção de ao menos $20 \%$ 
dos jovens no mercado formal de trabalho, um dos diferenciais do programa na gestão atual, não há ainda registros sobre seus impactos.

\section{Programa Bolsa Trabalho Renda22}

O Programa Bolsa Trabalho Renda foi implementado pela Secretaria de Desenvolvimento, Trabalho e Solidariedade (SDTS), do município de São Paulo (gestão 2001-2004), e integrou um conjunto de programas nomeados de redistributivos e dirigidos a diferentes faixas etárias. Além de atingir um número relativamente expressivo de jovens em apenas um município, se for considerado o total de beneficiários (57.397 entre os meses de julho de 2001 e setembro de 2004), essa iniciativa logo em sua formulação apresentava uma estratégia clara, diferente daquelas descritas anteriormente: diante dos elevados índices de desemprego juvenil, não deveria ser criado um programa de incentivo à inserção $0^{23}$, e sim um de ampliação do nível de escolaridade e formação, seguindo a lógica de experiências realizadas em países desenvolvidos e retardando a entrada do jovem no mercado de trabalho (cf. PMSP/SDTS, 2001, p. 6).

Entre os jovens mais pobres, haveria maior dificuldade em postergar esse ingresso, dada a centralidade da geração de renda por meio do trabalho, inclusive para o término da escolaridade básica. O gestor público chamava a atenção para o fato de que as crescentes dificuldades dos jovens em se inserir e permanecer no mercado de trabalho só seriam resolvidas a partir "da constituição de um cenário econômico de desenvolvimento sustentado", superando a baixa geração de postos de trabalho no país. Não obstante esse desafio mais amplo, em âmbito federal, o município poderia contribuir para que eles ampliassem sua escolaridade por meio de um programa de transferência de renda, sendo esse o objetivo geral do Programa Bolsa Trabalho, a despeito de seu nome ${ }^{24}$. Era dirigido, assim, a jovens entre 16 e 20 anos, estudantes ou formados no Ensino Médio, desempregados ou não, exercendo qualquer atividade remunerada, moradores da cidade de São Paulo há pelo menos dois anos e vivendo em famílias com renda familiar igual ou inferior a dois salários mínimos por pessoa. Todos os participantes do programa receberiam uma bolsa correspondente a $45 \%$ do salário mínimo, auxílio-transporte e seguro de vida coletivo, por um período que variava de seis meses a dois anos ${ }^{25}$. Ao mesmo tempo, deveriam realizar algum tipo de formação complementar, que não precisava estar voltada para o mundo do trabalho.
22. Inicialmente o programa foi chamado apenas de Bolsa Trabalho. Ao longo de sua implementação, com a criação de novas modalidades, como veremos a seguir, o programa passou a ser nomeado Bolsa Trabalho Renda.

23. Segundo Pochmann (2002, p. 102), “os equívocos de escassas açôes governamentais voltadas à pressão ao primeiro emprego juvenil mostram ser ineficientes, quando não ineficazes. Como empurrar para o mercado de trabalho os filhos das famílias pobres, quando não se criam vagas necessárias para todos? Esse tipo de ação resulta em transferir ao jovem a responsabilidade da própria condição de desemprego".

24. No limite, tratavase de uma bolsa para que o jovem não precisasse trabalhar, e não um programa de apoio à inserção no mercado de trabalho, permanecendo no seu título a ambigüidade.

25. A duração mais freqüente girou em torno de seis meses. 
26. Embora o processo de seleção tanto no Agente Jovem como no SCV esteja se modificando, por meio da implantação do cadastramento único, em suas origens a própria entidade executora realizava a seleção dos beneficiários, prática criticada na prefeitura municipal de São Paulo por afastar-se de critérios mais impessoais que impedissem eventuais distorções provocadas pelo clientelismo. Cada um desses dois caminhos encerra dilemas próprios, pois o recrutamento somente a partir de critérios técnicos, sem considerar as redes e as relaçóes primárias que os jovens mantêm, certamente dificulta qualquer ação no sentido da promoção de identidades coletivas e formas de ação mais solidárias.
Os objetivos específicos do programa concentravam-se em torno da oferta de capacitação adicional, não necessariamente vinculada ao mercado de trabalho; procurava potencializar a integração dos jovens nos seus bairros por meio do desenvolvimento de atividades comunitárias e buscava melhorar as condições de vida deles e de seu grupo familiar. Mas a lógica dominante em torno do perigo da violência atingiu também algumas das orientaçōes, o que pôde ser observado em seus objetivos preventivos: "Oferecer meios para que os jovens não desistam de estudar e nem, na ausência de vagas no mercado de trabalho, recorram a estratégias perigosamente fáceis de ganhar a vida" (Pochmann, 2002, p. 103).

Em um primeiro momento, o PBT Renda foi implementado em parceria com outros programas da própria SDTS, algumas secretarias do município e empresas municipais que se responsabilizavam pela formação dos jovens em atividades comunitárias. Dada a diversidade de parceiros, as atividades de formação foram variadas, desde jovens que efetivamente trabalhavam como agentes de trânsito ou no cadastramento em postos de saúde, até aqueles que receberam apenas formação em temáticas diversas: cooperativismo, teatro e informática, entre outras.

Ao final do primeiro ano de implementação, avaliações realizadas pela própria SDTS levaram a algumas mudanças no conjunto de seus programas e em especial no PBT Renda. Firmou-se um termo de cooperação técnica com a Organização das Nações Unidas (ONU), por intermédio da Organização das Nações Unidas para a Educação, a Ciência e a Cultura (Unesco), visando ao desenvolvimento de metodologia adequada. Além disso, o estabelecimento de convênio com outras entidades da sociedade civil foi facilitado, uma vez que caberia à Unesco, juntamente com a PMSP/ SDTS, a seleção de instituições para oferta de cursos e de projetos por meio de um processo de licitação cujos critérios básicos de avaliação seriam a qualidade e o menor preço.

É importante observar que a inscrição permaneceu aberta a todo e qualquer jovem e a seleção, realizada por técnicos da secretaria, obedecia a critérios estabelecidos pelo programa, sem passar pela apreciação das entidades executoras ${ }^{26}$. No interior do PBT Renda, cada vez mais a SDTS passou a fazer um esforço claro para incorporar ONGs com experiência no trabalho com o segmento juvenil. Sua hipótese era de que, dessa forma, seria possível desenvolver novas metodologias e adequar o trabalho ao público jovem, uma vez que avaliações realizadas nos dois primeiros anos do projeto tinham indicado alguns problemas nesse sentido. 
Outra mudança foi a elaboração de um documento de referência para a organização dos cursos. A partir dele, os cursos oferecidos deveriam ser organizados em dois módulos: um básico, de formação cidadã, com duração de até 480 horas, e outro específico, sem carga horária definida, em que seria privilegiada a realização de "atividades de utilidade coletiva" (PMSP/SDTS, 2002).

Embora os cursos oferecidos no módulo específico pudessem contribuir, no futuro, para algum tipo de inserção no mundo do trabalho, não era esse seu objetivo central. Havia a preocupação em oferecer formações que possibilitassem a constituição do que a equipe nomeava de "novos nichos de mercado", como montagem e desmontagem de exposições ou grafitagem, entre outras, sem que necessariamente fossem desenvolvidas estratégias que tornassem possível a geração de renda e de trabalho a partir dessa capacitação. Ao mesmo tempo, e essa era uma das ambigüidades do programa, essas novas orientaçôes conviviam com práticas consideradas de caráter convencional e com perspectiva mais profissionalizante, como auxiliar de escritório e auxiliar de raio-X, entre outras. Avaliações realizadas posteriormente indicaram a tendência dos jovens de desejar esse tipo de formação, ainda que um maior ou menor apreço pelos cursos parecesse depender menos da temática e mais da qualidade da formação oferecida. Raramente se possibilitava aos jovens escolher os cursos que queriam realizar, mas, nas poucas vezes em que isso ocorreu, houve predileção pelos de caráter claramente profissionalizante ou pelo exercício de algum tipo de trabalho (cf. Dieese, 2003; Cedec, 2003).

Outras mudanças realizadas no programa ao longo de sua implementação merecem ser assinaladas. Em relação à escolaridade, logo nos primeiros meses de cadastramento e nos primeiros levantamentos sobre o perfil dos beneficiários, a equipe percebeu que os jovens que procuravam o programa se distanciavam do perfil do público-alvo: grande parte já tinha finalizado ou estava finalizando o Ensino Médio, ou seja, a presença de jovens com baixa escolaridade era minoritária. Muitos estavam trabalhando em ocupaçôes precárias. Sendo assim, jovens com esse perfil passaram a poder inscrever-se no programa. Mesmo desempenhando uma ocupação, o jovem deveria integrar o PBT Renda, uma vez que seria mais bem aproveitado, individual e coletivamente, se, além de prosseguir nos estudos (inclusive curso superior), desenvolvesse atividades sociais e comunitárias, sendo retirado da "linha de frente" do mercado de trabalho (cf. Pochmann, 2003, p. 88). Essa descoberta veio atrelada à constatação daquilo que a SDTS 
27. Assim, outros programas passaram a integrar o PBT Renda: o Programa Bolsa Trabalho Cursinho e o Programa Bolsa Trabalho Estágio para jovens entre 16 e 29 anos e o Programa Bolsa Trabalho Emprego para jovens entre 16 e 24 anos. Além da ampliação da faixa etária, tratava-se de programas dirigidos a jovens que já tinham completado o Ensino Médio. chamou de "nova pobreza" ou "nova exclusão", que estaria atingindo jovens não migrantes, com escolaridade mais elevada e membros de famílias pouco numerosas ${ }^{27}$.

De certo modo, essas mudanças, sobretudo a ampliação do programa, também parecem ter sido pautadas por resultados de avaliações realizadas por instituições externas contratadas para tal fim, além daquelas realizadas pela própria equipe.

Em um dos distritos onde o Dieese (2003) realizou grupos focais junto a jovens egressos, a bolsa emergiu como a principal motivação para a inscrição no programa, e muitos tomaram conhecimento da iniciativa por meio de suas famílias e professores. As qualidades ressaltadas foram a possibilidade de ter uma ocupação fora de casa, o contato com idosos e a qualidade dos instrutores, mais abertura para a vida e para as pessoas e melhoria no relacionamento com a família e a comunidade. Quanto aos principais aspectos negativos, os jovens destacaram o excesso de faltas e atrasos, de alunos e monitores, a falta de local fixo para o desenvolvimento das atividades e o descumprimento do horário por parte dos bolsistas. As principais sugestões também elucidam aspectos significativos do programa: "Mais organização, supervisão para garantir a freqüência, pontualidade e efetiva realização de tarefas por parte dos alunos, oportunidade para os jovens que não conseguiram se inscrever ou desistiram, local certo para as atividades" (Dieese, 2003, p. 150).

De certo modo, os entraves e as características dos programas federais também se reproduziram, em muitas situaçôes, no âmbito da iniciativa municipal. Mas, no caso do Programa Bolsa Trabalho Renda, esses resultados acabaram por reforçar a necessidade de atentar para o próprio processo de formação dos jovens, uma vez que boa parte das reclamaçōes fez referência à falta de preparo dos educadores, à inadequação dos espaços e até mesmo à seriedade na condução do processo.

Com relação ao mundo do trabalho, os jovens solicitavam "comprovantes" dos trabalhos e atividades realizados, porque poderiam, de algum modo, contribuir na busca de emprego, o que denota a centralidade que a questão do trabalho parece ter entre os bolsistas, reiterada pela angústia que manifestam com a dificuldade concreta de consegui-lo e pela busca incessante de "qualquer trabalho" durante e após a saída do programa. Além de reiterar boa parte das constataçóes do Dieese (2003), esse último aspecto foi ainda mais enfatizado na avaliação realizada pelo Cedec (2003) a partir de um estudo etnográfico realizado em um dos distritos do muni- 
cípio. Apontando para uma forte ética que valoriza o trabalho, o estudo observa que a participação no programa não impediu que muitos dos jovens continuassem trabalhando em empregos precários ou que se preocupassem intensamente com o emprego durante a participação no PBT Renda. Outros aspectos significativos levantados pelo Cedec foram: o fato de os beneficiários perceberem os programas como importantes mas ao mesmo tempo paliativos; a centralidade do papel da educação escolar, e não dos programas, para o rompimento do ciclo de pobreza, percepção presente entre os adultos entrevistados; os vários problemas no fluxo de informação e comunicação entre os diferentes atores envolvidos.

Embora com uma estratégia mais claramente definida, de enfrentamento da situação do jovem no mundo do trabalho pelo retardamento de sua inserção, e com uma importante capacidade de realizar mudanças ao longo do processo de implementação, o formato geral do PBT Renda continuou muito próximo dos demais programas aqui observados. $\mathrm{O}$ recebimento da renda permaneceu atrelado tanto ao retorno aos estudos ou continuidade deles, quanto à realização de atividades de formação, tidas como obrigatórias. No detalhamento dessas atividades, o desenvolvimento de um projeto de intervenção na comunidade era apontado como desejável, mas não obrigatório, diferentemente dos programas Agente Jovem e SCV. Entretanto, a exigência de uma contrapartida ao recebimento da bolsa mantém-se: o retorno à escola e a realização de atividades de formação de caráter complementar. $\mathrm{O}$ atendimento à forte demanda juvenil por trabalho não foi considerado uma meta desse projeto, voltada para outras modalidades do programa que não atingiram um contingente expressivo de jovens, o que acabou frustrando muitas das expectativas.

\section{Pontos de convergência}

Embora empreendidos no interior de diferentes tipos de orientação, os programas aqui analisados assumem um formato comum, indicando adesão a alguns pressupostos que tendem não só a ser aceitos, como também a se disseminar ${ }^{28}$.

Um aspecto relevante dessas convergências incide sobre o fato de as ações considerarem a possibilidade de transferir aos jovens algum tipo de renda sob a forma de bolsa, operando com princípios redistributivos. Algumas avaliações já empreendidas apontam o quanto essa renda é importante para esses jovens, principalmente para apoio e, ao mesmo tempo,
28. Antes da área pública, essa modalidade de ação foi bastante difundida entre ONGs e fundações empresariais. No âmbito público federal, novos programas assumem formato semelhante, como, no atual governo, o Projeto Agente Cultura Viva, produto de uma parceria do Ministério da Cultura com o Ministério do Trabalho, que oferece bolsas de $\mathrm{R} \$ 150,00$ por um período de seis meses a jovens entre 16 e 24 anos, com a obrigatoriedade da frequiência à escola e a participação em programas de capacitação. A contrapartida é a realização de trabalho voluntário com uma carga de seis a dez horas semanais. O Pró-Jovem propóe como eixo central a oferta de escolaridade para jovens que não concluíram o Ensino Fundamental (cf. Novaes, 2005). 
29. $\mathrm{O}$ acesso direto do jovem a esse tipo de remuneração também não constitui unanimidade, pois em algumas perspectivas prevalecentes no âmbito da assistência social é defendida a centralidade da família como alvo da ação do Estado, em detrimento de programas de transferência de renda voltados diretamente para adolescentes e jovens. Sem adentrar nesse debate, vale a pena assinalar que, provavelmente, a tutela e a subordinação dos jovens à vida familiar só tende a aumentar em um momento do ciclo de vida em que a maioria aspira por maior autonomia e independência (cf. Singly, 2000).

30. Uma explicação possível para a permanência dessas posições reside na eterna desconfiança da capacidade dos pobres no uso dos recursos monetários. independência em relação à família ${ }^{29}$. Embora o montante auferido seja percebido mais como "privilégio" do que como direito, ele constitui um dos principais motivos, ainda que não o único, para a permanência dos jovens nos programas. Para muitos, o pequeno valor recebido, a incerteza diante da continuidade da iniciativa, de sua permanência como beneficiários, e o desejo de não ser "dependentes" do Estado reiteravam a necessidade e a prática de continuar procurando trabalho ou de realizar atividades precárias (cf. Cedec, 2003; Camacho, 2004, Leão, 2004).

Mas um pressuposto, igualmente recorrente em todas as açôes, reside na idéia da contrapartida necessária para que a transferência de recursos escape de um viés "meramente assistencialista", incluindo, assim, um possível rompimento com a lógica da filantropia. Esse aspecto tende a ser assumido praticamente como uma orientação legítima e quase natural dos programas que têm os jovens como alvo, mas não deveria obscurecer a existência de orientações divergentes, estimulando o debate em torno das diferentes visōes prevalecentes sobre as relações entre o Estado e os usuários de programas que envolvem alguma distribuição de renda no Brasil.

Grande parte dos gestores consideram que, para romper com a idéia da filantropia ou do assistencialismo, as iniciativas de transferência de renda demandam do indivíduo ações que estimulem seu engajamento ativo, eliminando riscos de sujeição ou atitudes de "dependência" em relação ao Estado $^{30}$. No entanto, há algumas décadas a idéia de uma renda assegurada pelo Estado aos cidadãos tem envolvido pressupostos e orientações diversos, constituindo, nas diferentes versões, modos de concepção do sistema de proteção e de direitos tendo em vista o papel fundamental do Estado no fomento da justiça e na atenuação das desigualdades sociais acentuadas com a crise do mundo do trabalho e do emprego assalariado.

Uma versão importante da idéia de contrapartida é formulada no interior da crise do Estado-Providência e do regime assalariado. Por meio dela, pretende-se restabelecer a solidariedade social a partir da ação pública, constituindo, além da transferência de renda, uma espécie de distribuição de responsabilidades que mobilize os cidadãos para a sua efetiva integração na ordem nacional. Zaluar sintetiza essas orientações de modo claro:

\footnotetext{
Não haveria mais assistidos a socorrer, mas pessoas com diferentes utilidades sociais, cuja capacidade deveria ser sempre aproveitada. Nele [Estado Ativo Providência] também haveria a socialização radical dos bens e das responsabilidades. Uma nova concepção de solidariedade é mobilizada na ideologia desse Estado: não
} 
é nem a caridade privada, nem o bem-estar advindo dos direitos sociais, nem a mutualidade do solidarismo do século XIX. Refazer a nação, lema dessa ideologia, significa fomentar a solidariedade advinda do pertencimento a uma mesma comunidade nacional, na qual a seguridade é nacional - o novo sentido do social, visto que a questão social é nacional -, solidariedade que se traduz em direito e dever à integração (Zaluar, 1997, p. 32) ${ }^{31}$.

De outra parte, os debates sobre a renda mínima universal e incondicional têm reunido vários defensores, agregados na BIEN - Rede Européia da Renda Básica -, fundada em $1986^{32}$. Nesse âmbito, os pressupostos da transferência seriam redistributivos, sem distinção de origem, raça, sexo, idade, condição civil ou mesmo situação socioeconômica, e sem vinculação a qualquer idéia de contrapartida (cf. Silva et al., 2004).

Adotada como pressuposto naturalizado nos programas destinados aos jovens, a idéia da contrapartida é multifacetada. Ela pode compreender, no seu âmbito mais restrito, apenas a freqüência obrigatória à escola, mas também pode incidir sobre a necessária presença em atividades de cunho socioeducativo e a participação em ações de engajamento comunitário, em geral propostas pelas instituiçóes parceiras responsáveis pela execução do programa no âmbito local.

Nesse formato comum, em geral as propostas educativas são executadas a partir de uma base material precária e com um corpo de responsáveis educadores sociais, animadores culturais etc. - de baixa formação técnica ou mesmo escolar. Com raras exceções, demandam poucos recursos materiais quanto a equipamentos e podem ser realizadas a partir de um baixo custo operacional $^{33}$. Essas práticas, apesar de um discurso de engajamento e de promoção da participação, podem acentuar mecanismos perversos de reprodução de uma base humana e material precária nos programas sociais, reiterando a idéia de que não é preciso oferecer muito aos pobres.

Mas as propostas envolvem um campo diversificado de ações socioeducativas que podem estar agrupadas na idéia de educação não escolar ou não convencional na acepção de Luiza Camacho ${ }^{34}$ (2004), compondo um conjunto de práticas muito assemelhadas: palestras, cursos e oficinas. Na maioria dos casos, como já foi relatado, o programa/projeto pressupõe uma formação geral voltada para o tema da cidadania e em alguns casos ocorre um módulo articulado ao aprendizado de habilidades do mundo do trabalho, sem constituir rigorosamente formação profissional. As atividades socioeducativas pressupõem, além de seu caráter obrigatório - para os jovens, as
31. Essas posiçóes, defendidas por Rosanvallon (1981), não são totalmente endossadas por Castel (1995), para quem a contrapartida deveria ser acompanhada de políticas inclusivas asseguradas pelo Estado, centradas no emprego. Como afirma Zaluar, esse debate ocorre na crise financeira do Estado, que "reacendeu a preocupação com os que evitam o trabalho por terem desenvolvido o 'vício' da dependência, tornando-se parasitas dos demais" (Zaluar, 1997, p. 32). Um balanço do conjunto de teses a favor do rendimento mínimo incondicional está em Benarrosh (1998). A revista MAUSS também dedicou um número especial a essa questão (cf. Caillé et al., 1996).

32. Destacam-se, como membros da rede, Klaus Offe, Guy Standing, Phillipe Van Parijs e, no Brasil, Eduardo Suplicy e Maria Ozanira da Silva e Silva (Silva et al., 2004).

33. No entanto, a implantação de todos esses dispositivos intermediários acaba por absorver recursos não desprezíveis dos programas que po- 
deriam ser direcionados diretamente ao públicoalvo se não houvesse o desenho desse conjunto de contrapartidas.

34. A designação "não convencional", de acordo com Camacho (2004), recobre melhor o sentido dessas práticas socioeducativas, já que elas são formalizadas e institucionalizadas, não se adequandoà idéia de educação não formal. margens de escolha, quando existem, situam-se na sugestão de temas -, algum tipo de orientação para a prestação de serviços à comunidade e o desenvolvimento de atividades voluntárias tidas como úteis e importantes para os bairros onde esses jovens residem.

Apesar de algumas variações, verifica-se a tendência de configurar um campo novo de problemas que demandam análise independentemente do sucesso ou eventual fracasso das iniciativas. Tais questôes incidem sobre o modo como se constitui um campo de orientações normativas capazes de definir o que seria importante destinar aos jovens pobres brasileiros, que passam a interagir com o poder público ou com segmentos da sociedade civil a partir de sua inserção nesse quadro de ações.

\section{Grupo alvo e escolaridade}

Em geral, os programas destinados a segmentos de baixa renda pressupõem a simples obrigatoriedade da matrícula na escola pública como fator de inclusão. Nesse caso, por hipótese, como afirma Silva et al. (2004), a contrapartida seria um meio para promover o usuário, pois a falta de acesso à escola seria fator agravante no processo de exclusão social. Se considerarmos a importância da escolarização em massa de crianças, essa contrapartida pode sinalizar efeitos inclusivos reais. Mesmo assim, muitos estudos ressaltam que é preciso transformar as condições de funcionamento e a qualidade da educação pública, uma vez que o abandono escolar precoce muitas vezes decorre de fatores internos ao sistema de ensino, incapaz de acolher, efetivamente, os grupos menos privilegiados da população brasileira.

Mas, ao ser estendida aos adolescentes e jovens, a mera obrigatoriedade da frequiência à escola acentua mais ainda algumas ambigüidades. Os usuários jovens, alvos dos programas e sempre definidos por sua condição de maior "vulnerabilidade", situam-se entre os grupos precocemente excluídos da escola, com significativa distorção série/idade ou com importantes dificuldades, já consolidadas, na construção de uma relação positiva com a instituição escolar. A mera exigência de retorno à mesma escola que não foi capaz de lidar antes com essas situaçôes apenas sinaliza a permanência dos mesmos processos de exclusão. Em muitos casos, o retorno à escola é computado no programa de forma burocrática, funcionando apenas como mais um controle a ser estabelecido sobre os jovens, pouco interferindo na real interação que esses segmentos mantêm com a instituição escolar. 
Outra situação, observada por exemplo no SCV e no PBT Renda, incide sobre o fato de que muitos jovens buscam esses programas após concluírem sua escolaridade, pois as condiçôes materiais da pobreza nem sempre são impeditivas da frequiência à escola, que isoladamente não garante a superação da precariedade material em que eles estão imersos. Muitos usuários do PBT Renda já haviam concluído o Ensino Médio (cf. Pochmann, 2003), e no SCV alguns chegaram a alterar sua escolaridade, rebaixando-a, para adaptarse às exigências estabelecidas pelas normas vigentes (cf. Leão, 2004). No programa promovido pela Prefeitura de São Paulo, os gestores perceberam as novas condições em que a expansão escolar ocorre, mesmo no interior dos segmentos mais pobres, e não criaram obstáculos à freqüência desses jovens com escolaridade básica concluída. Esses dados iniciais do aumento da escolaridade em situação de pobreza contribuíram para a consolidação da idéia de uma nova exclusão. Conforme análises de Pochmann,

[...] no período posterior a 1980, o Brasil afastou-se do crescimento econômico, agravando os problemas sociais, sobretudo em relação à nova exclusão (os deserdados do crescimento econômico). Ou seja, as políticas de corte neoliberal implementadas nesses anos, ao impactarem fortemente a economia do país, geraram um novo contingente de excluídos, mas de perfil diferente do tradicional. Se antes a população excluída geralmente tinha baixa escolaridade, vinha de famílias numerosas, era migrante e tinha ocupação mal remunerada, hoje, na nova exclusão, as pessoas não são analfabetas, têm alguma escolaridade, vêm de famílias pequenas, já são cidadãos urbanos, mas estão desempregadas (Pochmann, 2003, p. 19).

Mas outras conseqüências podem ser derivadas dessa situação: uma delas é o paralelismo das atividades não convencionais de caráter socioeducativo com as práticas escolares propriamente ditas. Sem interação e desarticulado dos sistemas escolares, esse conjunto de ações começa a criar uma rede paralela não convencional, destinada aos jovens pobres, que muitas vezes é uma versão piorada e precária da prática educativa da escola pública. Pouco se aprende de significativo e não há apropriação de ferramentas que possa interferir nas condiçôes em que ocorre a relação desses jovens com o conhecimento escolar.

Quando mais bem-sucedidas, as práticas não convencionais podem favorecer certas habilidades pessoais dos jovens no âmbito de suas interações (superação da timidez, facilidade de trabalho em grupo, entre outras), mas em geral esses efeitos são pouco absorvidos pelas orientações do mundo 
35. Evidencia-se, também, a quase total ausência de políticas educacionais articuladas a esses programas, na medida em que poderiam ser parceiras capazes de participar da redefinição do tipo de escolaridade e de ação educativa adequado aos jovens.
36. Sobre os vários sentidos contidos na idéia de promoção da cidadania na sua relação com o sistema educativo, consultar Barrière e Martuccelli (1998). escolar. Se as atividades são inovadoras, os jovens tendem a estabelecer comparações com a educação escolar, aumentando provavelmente sua reflexão e crítica à escola, muitas vezes sem a contrapartida dos caminhos que fortaleceriam uma capacidade de interferência das práticas educativas no interior da rede pública de ensino. De modo paradoxal, a crítica destituída de capacidade de ação pode favorecer um maior distanciamento da vida escolar, sobressaindo uma relação meramente instrumental que reforça o caráter meritocrático e credencialista da educação escolar ${ }^{35}$.

\section{Por que programas socioeducativos?}

A imensa maioria dos programas e dos projetos destinados aos jovens admite e valoriza uma ação de natureza socioeducativa, mas não explicita os pressupostos que induzem a esse apoio. Trata-se de uma adesão generalizada que não incide, aparentemente, sobre as deficiências propriamente escolares dos sistemas de ensino, pois em nenhum momento as iniciativas pretendem substituir ou complementar a ação da instituição escolar, nos aspectos relativos às habilidades pressupostas nas aprendizagens e nos processos de transmissão do conhecimento sistematizado. A melhor qualificação dos jovens tendo em vista sua inserção no mundo do trabalho não tem sido prioritária, tratando-se na maior parte das vezes de atividades que estabelecem sondagens ou incursões na esfera da profissionalização, sem assumir, rigorosamente, essa orientação como eixo estruturante das ações.

Dois caminhos analíticos podem ser trilhados, e cada um merece seu aprofundamento. $\mathrm{O}$ primeiro diz respeito às concepçóes de cidadania que emergem dessas ações socioeducativas e o segundo, menos explícito, está situado na gestão do tempo livre dos jovens pobres.

Ao que tudo indica, as deficiências identificadas nos sistemas de ensino estariam radicadas não só em seus aspectos pedagógicos, mas na própria missão socializadora da escola, que não estaria formando os futuros cidadãos ${ }^{36}$. A ênfase nessa dimensão acaba por fazer emergir um conceito de cidadania muito mais ligado à idéia de atividade educativa intencional, marcada pelo civismo ou, em uma versão mais amena, pela absorção de valores ligados à civilidade, que seriam a expressão de um programa civilizador não cumprido pela instituição escolar. Trata-se mais de ensinar do que de praticar as virtudes da cidadania, deslocando-se o foco das práticas para a ação intencional e sistemática, veiculada principalmente pela transmissão de alguns conteúdos. 
Além de estabelecer um diagnóstico sobre o fracasso da escola e privilegiar a dimensão socializadora da idéia da cidadania, os conteúdos inscritos na idéia de direitos tornam-se esvaziados ou ao menos atenuados. Assim, pode adquirir dominância o pressuposto de que jovens e adolescentes - pobres - precisam ser atingidos por alguma ação que lhes ensine algo sobre a vida em comum, permanecendo submerso o conteúdo da cidadania como direito e como prática (cf. Loncle-Mouriceau, 2001). Se a cidadania fosse concebida principalmente na chave dos direitos, esses adolescentes e jovens seriam prioritariamente alvos da ação pública para a promoção da igualdade de acesso aos bens dos quais são de modo sistemático excluídos: educação, saúde, cultura, lazer e trabalho, entre outros. A realização de direitos implicaria a extensão de equipamentos e de serviços públicos, ausentes nos bairros onde vivem esses jovens, tendo em vista a democratização do acesso à cultura e ao lazer, sendo algo mais do que a formulação de programas que, sozinhos, passam a ser sinônimo de políticas públicas de juventude e de promoção da cidadania.

\section{0 paradoxo da ação voluntária compulsória}

Os programas, por serem focalizados, atingem um segmento de jovens que vive em territórios destituídos de serviços básicos, predominando uma quase absoluta ausência do Poder Público. Espera-se que essa população retorne à escola pública para concluir seus estudos (sabemos que não são poucas as dificuldades inscritas nessa meta), participe, quase de modo diário, de atividades educativas em alguma sede de associação local e, além de disso, promova o desenvolvimento do seu bairro, quando o Estado e outras instituições não o fizeram. Por que esse conjunto de exigências e tais expectativas se dirigem apenas aos jovens pobres? Por que jovens de classes médias e de elite, alguns alunos de escolas técnicas federais ou de universidades públicas, usufruindo serviços gratuitos mantidos pelos impostos, não estão também submetidos a qualquer contrapartida comunitária, sabendo-se que teriam facilidades para essa ação, diante de seu capital cultural e social? Ocorre mais uma exigência voltada apenas aos pobres, aqueles que no discurso são considerados desprovidos de direitos?

Não se nega o potencial da ação voluntária e das energias criadoras dos segmentos juvenis que conseguem mobilizar-se para o agir em comum mesmo em situações de vida extremamente precárias (cf. Melucci, 1991; Sposito, 2000; Novaes, 1997). Mas, de certo modo, ocorre um novo 
37. Uma crítica à idéia de protagonismo juvenil pode ser encontrada em Castro (2002), Zibas et al., (2004 e Corti e Souza (2005). Essas orientações privilegiaram a idéia como um instrumento pedagógico esvaziado de seus conteúdos sociopolíticos.

38. Sobre o descompasso entre a racionalidade do gestor que atribui ao usuário uma racionalidade estreita, distante das "boas razôes" dos assistidos, consultar o estudo de François Dubet sobre os usuários de programas de renda mínima na França (cf. Dubet, 2001). ocultamento ou naturalização das condições em que as desigualdades sociais operam, pois na ausência de direitos assegurados resta aos atores jovens, muitas vezes sem nenhum apoio de caráter mais duradouro, a tarefa de construir um projeto voltado para o "desenvolvimento local ou comunitário", deslocando-se para o sujeito a responsabilidade de empreendimentos que não seriam a rigor de sua alçada. Sempre há o risco da mera farsa ou do simulacro de projeto de ação coletiva. Mas, se os jovens são responsáveis pelo projeto, provavelmente poderão sentir-se também responsáveis por seu fracasso, individualizando situações que encontram seus limites nas barreiras estruturais das desigualdades. Como afirma Dubet, as instituiçôes passam por um processo de mutação que altera a natureza da dominação e os indivíduos são convidados a agir "livremente" nas categorias que lhes são impostas. Assim, o dominado é convidado a ser o mestre de sua identidade e de sua experiência social, ao mesmo tempo em que é posto em situação de não poder realizar esse projeto (cf. Dubet, 2002).

Como se trata de uma tarefa praticamente irrealizável, na maioria das vezes o "protagonismo" juvenil e a mobilização dos jovens permanecem no campo do discurso que dissimula a inexistência de práticas inovadoras ${ }^{37}$. Por outro lado, o caráter fragmentado da iniciativa, que, devido a seu viés focalizado, absorve o público apenas a partir de critérios rígidos de renda, dificulta a possibilidade de ação coletiva e a formação de práticas mais solidárias, pois não reconhece os modos de vida e as redes nas quais os jovens estão mergulhados em sua experiência cotidiana.

Verifica-se, assim, que o conjunto desses programas pouco avança no diálogo efetivo com os jovens, entendendo que eles não são apenas público-alvo, mas sujeitos capazes de participar efetivamente das definiçôes que dizem respeito aos seus interesses e à sua própria vida. Sob esse ponto de vista, mantém-se a distância entre as razões do Poder Público, proponente das ações, e as orientações na vida cotidiana daqueles que permanecem na base da sociedade ${ }^{38}$. Quando essa distância pretende ser superada, vem acompanhada da tentativa de impor aos jovens as lógicas dos responsáveis pela ação, aumentando o grau de expectativas permanentemente frustradas.

Tendo em vista as ambigüidades dessas propostas, há outro caminho que merece ainda ser analisado, como hipótese para a disseminação tão rápida dessas ações. Trata-se de uma forma de gestão institucional do tempo livre e ocioso dos jovens pobres, considerados uma ameaça para a ordem pública. De vítimas, esses segmentos rapidamente são transformados 
em réus, pois a inatividade forçada seria necessariamente a ante-sala da violência e do crime.

Para os jovens pobres, o desejo de preenchimento de seu tempo livre, além do espaço escolar, incide de modo articulado sobre a possibilidade de acesso à fruição, quer no âmbito da cultura, quer no âmbito do lazer (cf. Brenner et al., 2005; Sposito, 2005; Guimarães, 2005). Mas, no mesmo processo em que é constituída a aspiração de viver a experiência juvenil, por meio de "uma trégua" em relação às exigências do mundo adulto (cf. Dayrell, 2005), os jovens pobres também querem ter acesso ao mundo do trabalho e não postergam essa busca para um tempo futuro. Para muitos, a ocupação remunerada é a melhor condição de criação da possibilidade de um tempo livre mais prazeroso e do acesso ao lazer predominantemente mercantilizado (cf. Brenner et al., 2005).

Assim, nos interstícios da crise do mundo do trabalho, da ausência de direitos efetivamente assegurados de acesso ao lazer e aos bens culturais, e de um sistema educativo capaz de acolher seu novo público, ocorrem os programas de transferência de renda aos jovens, incapazes por si sós de assegurar transformações mais densas nessas esferas.

Essas questôes, circunscritas pelo processo sociocultural de construção de uma imagem sobre a juventude no Brasil, alicerçada no medo e na percepção de que os jovens pobres são potencialmente perigosos e constituem um problema para a sociedade, tornam ainda mais intrigantes as açôes públicas que têm como meta transferir renda para eles. Para além do evidente benefício que o acesso à renda promove, as exigências de contrapartida constituem novos modelos que, se não estiverem submetidos à crítica, serão potencialmente disseminadores de novas formas de dominação, obscurecidas pelo discurso da inserção social e da cidadania.

\section{Referências Bibliográficas}

Abramo, Helena \& Branco, Pedro Paulo (orgs.). (2005), Retratos da juventude brasileira: análises de uma pesquisa nacional. São Paulo, Instituto da Cidadania/Fundação Perseu Abramo.

Bango, Julio. (2003), "Políticas públicas de juventude na América Latina: identificação de desafios”. In: Freitas, Maria Virginia \& PAPA, Fernanda de Carvalho (orgs.). Políticas públicas de juventude: juventude em pauta. São Paulo, Cortez/Ação Educativa/Fundação Friedrich Ebert Stiftung. 
Barrière, A. \& MartucCelli, D. (1998), “La citoyenneté à l'école: vers la définition d'une problématique sociologique”. Revue Française de Sociologie, XXXIX-4.

Benarrosh, Yolande. (1998), "Pour ou contre un revenun minimum inconditionnel”. Texto apresentado no Seminaire de Recherche pour les Personnels et Administrateurs de l'Association vers la la Vie pour l'Éducation de Jeunes, set.

Brenner Ana Karina et al. (2005), "Culturas do lazer e do tempo livre dos jovens brasileiros". In: Abramo, H. e Branco, Pedro Paulo (orgs.). Retratos da juventude brasileira: análises de uma pesquisa nacional. São Paulo: Instituto da Cidadania/ Fundação Perseu Abramo.

Caillé, Alain et al. (1996), "(Débat) Le revenu minimum inconditionnel avec Robert Castel". Revue du MAUSS, 7.

CAmaChO, Luiza. (2004), "Projeto Agente Jovem: ação, programa ou política pública de juventude?”. Trabalho apresentado na XXVII Reunião Anual da ANPEd, Caxambu.

CASTEL, Robert. (1995). Les métamorphoses de la question sociale, une chronique du salariat. Paris, Librairie Fayard.

Castro, Mary Garcia. (2002), "O que dizem as pesquisas da Unesco sobre juventudes no Brasil: leituras singulares”. In: Novaes, R., Porto, M. \& Henriques, R. (orgs.). Juventude, cultura e cidadania. Rio de Janeiro, Iser.

Castro, Mary Garcia \& Abramovay, Miriam. (1998), "Cultura, identidades e cidadania: experiências com adolescentes em situação de risco”. In: CNPD. Jovens acontecendo na trilha das políticas públicas. Brasília, CNPD.

. (2003), "Por um novo paradigma do fazer políticas - políticas de/para/com juventudes". Revista Brasileira de Estudos Populacionais, 19 (2), jul./dez.

CEDEC. (2003), Por uma etnografia participativa: desafios dos programas redistributivos na periferia paulistana. São Paulo, Cedec, dez.

CEF - Caixa Econômica Federal. (2005), “Agente Jovem - manual de orientações”. Brasília, www.caixa.gov.br.

Corrochano, M. C. \& GouvêA, J. L. (2003), "A dança das cadeiras: os jovens e os mundos do trabalho no Brasil contemporâneo". In: Tokman, V. et al. Desemprego juvenil no Cone Sul: uma análise de década. São Paulo, Fundação Friedrich Ebert.

Corti, Ana Paula \& SouzA, Raquel. (2005), Diálogos com o mundo juvenil: subsídios para educadores. São Paulo, Ação Educativa.

DÁVILA, Oscar. (2003), "Da agregação programática à visão construtiva de políticas de juventude”. In: Freitas, Maria Virginia \& PAPA, Fernanda de Carvalho (orgs.). Políticas públicas de juventude: juventude em pauta. São Paulo, Cortez/Ação Educativa/Fundação Friedrich Ebert Stiftung.

DAYRELl, Juarez. (2005), A música entra em cena: o rap e o funk na socialização da juventude. Belo Horizonte, Editora da UFMG.

168 Tempo Social, revista de sociologia da USP, v. 17, n. 2 
DiEESE. (2003), Identificação das mudanças ocorridas com os beneficiários dos programas sociais da Prefeitura do Município de São Paulo desenvolvidos pela Secretaria do Desenvolvimento, Trabalho e Solidariedade (SDTS). São Paulo, Dieese.

DubEt, François. (2001), “Une 'réduction' de la rationalité de l'acteur. Pourquoi sortir du RMI”. Revue Française de Sociologie, 42 (3): 407-436.

. (2002), Le déclin de l'institution. Paris, Seuil.

. (2004), "La jeunesse est une épreuve”. In: Dubet, François, Galland, Olivier \& Deschavanne, Éric. Comprendre: les jeunes [Revue de Philosophie et de Sciences Sociales, 5]. Paris, Presses Universitaires de France.

Guimarães, Nadya Araujo. (2005), "Trabalho: uma categoria-chave no imaginário juvenil?”. In: Abramo, H. \& Branco, Pedro Paulo (orgs.). Retratos da juventude brasileira: análises de uma pesquisa nacional. São Paulo, Instituto da Cidadania/ Fundação Perseu Abramo.

LEÃO, Geraldo. (2004), “A gestão da pobreza juvenil: uma análise de um programa federal de inclusão social para jovens pobres". Trabalho apresentado na XXVII Reunião Anual da ANPEd, Caxambu.

Lefebvre, Henri. (1980), La présence et l'absence: contribution à la théorie des représentations. Paris, Casterman.

LonCle, Patrícia. (2003), L'action publique malgré les jeunes: les politiques de jeunesse en France de 1870 à 2000. Paris, L'Harmattan.

Loncle-Moriceau, Patrícia. (2001), "La jeunesse: ambivalences et ambiguités autour d'une catégorie d'intervention publique". In: Vulbeau, A. (dir.). La jeneusse comme ressource. Toulouse, Érès.

Madeira, Felicia. (2004), "A improvisação na concepção de programas sociais. Muitas convicções, poucas constatações: o caso do primeiro emprego". São Paulo em Perspectiva, 18 (2): 78-94.

MDS - Ministério do Desenvolvimento Social e Combate à Fome. (2005a), "Projeto Agente Jovem de Desenvolvimento Social e Humano”. Brasília, www.mds.gov.br. (2005b), "Relatório de Avaliação do Projeto Agente Jovem”. Brasília, www.mds.gov.br.

Melucci, Alberto. (1991), Linvenzione del presente. Bologna. Il Mulino.

Ministério da Justiça (MJ). (2000), “Termo de referência do Serviço Civil Voluntário. Brasília, Plano Nacional de Qualificação do Trabalhador e Programa Nacional de Direitos Humanos (PNDH)". In: www.mj.gov.br/programas de governo.

MPAS - Ministério da Previdência e Assistência Social. (2001a), "Projeto Agente Jovem de Desenvolvimento Social e Humano”. Brasília, www.mds.gov.br/legislação/ portarias/. 
. (2001b), Guia de gestores do Programa Agente Jovem de Desenvolvimento Social e Humano. Brasília.

(s.d.), Guia de capacitação - Núcleo básico do Projeto Agente Jovem de Desenvolvimento Social e Humano. Brasília.

MTE - Ministério do Trabalho e Emprego. (2005), "Serviço Civil Voluntário". Brasília, www.mte.gov.br.

Novaes, Regina. (1997), "Juventudes cariocas: mediações, conflitos e encontros culturais”. In: Vianna, H. (org.). Galeras cariocas. Rio de Janeiro, Editora da UFRJ. . (2005), Juventude, oportunidade e apostas. Brasília, www.presidencia. gov.br/ secgeral/juventude/arquivos.

PMSP/SDTS - Prefeitura municipal de São Paulo. Secretaria do Desenvolvimento, Trabalho e Solidariedade. (2001), Bolsa Trabalho: Manual do Beneficiário. São Paulo.

(2002), Projeto formação cidadã, capacitação ocupacional e aprendizagem em atividades de utilidade coletiva: diretrizes para o módulo específico. São Paulo.

Pochmann, M. (org.). (2002), Desenvolvimento, trabalho e solidariedade: novos caminhos para a inclusão social. São Paulo, Cortez/Fundação Perseu Abramo.

. (2003), Outra cidade é possivel: alternativas de inclusão social em São Paulo. São Paulo, Cortez.

Rodríguez, Ernesto. (2001), "Juventud y desarrollo en América Latina: desafíos y prioridades en el comienzo de un nuevo siglo”. In: PІECK, Enrique (coord.). Los jóvenes y el trabajo: la educación frente a la exclusión social. México, IA/Unicef/ Cinterfor-OIT/RET, pp. 27-58.

Rosanvallon, Pierre. (1981), La crise de l'État-providence. Paris, Seuil.

RuA, Maria das Graças. (1998), “As políticas públicas e a juventude dos anos 90”. In:

CNPD. Jovens acontecendo na trilha das politicas públicas. Brasília.

Secretaria Nacional de Políticas Públicas de Emprego. (2002), O caso do Serviço Civil Voluntário. Série: Avaliações do Planfor, Brasília, Ministério do Trabalho e Emprego (MTE), www.mte.gov.br.

SiLva, Maria Ozanira da Silva et al. (2004), A política social brasileira no século XXI. São Paulo, Cortez.

Singly, François de. (2000), "Penser autrement la jeunesse". Lien Social et Politiques - RIAC, 43: 9-21.

SolA, Lourdes. (1998), “Juventude, comunidade política e sociedade civil”. In: CNPD. Jovens acontecendo na trilha das politicas públicas. Brasília.

Sposito, M. P. (2000), "Algumas hipóteses sobre as relações entre juventude, educação e movimentos sociais". Revista Brasileira de Educação, 13: 73-94, jan./abr., São Paulo, Anped.

170 Tempo Social, revista de sociologia da USP, v. 17, n. 2 
(2003), “Trajetórias na constituição de políticas públicas de juventude no Brasil”. In: Freitas, Maria Virginia \& PAPA, Fernanda de Carvalho (orgs.). Politicas públicas de juventude: juventude em pauta. São Paulo, Cortez/Ação Educativa/Fundação Friedrich Ebert Stiftung.

. (2005), "Algumas reflexões e muitas indagaçōes sobre as relaçōes entre juventude e escola no Brasil". In: Abramo, H. e Branco, Pedro Paulo (orgs.). Retratos da juventude brasileira: análises de uma pesquisa nacional. São Paulo, Instituto da Cidadania/Fundação Perseu Abramo.

Sposito, M. P. \& ConTi, A. P. (2002), "A pesquisa sobre juventude e os temas emergentes”. In: Sposito, Marilia P. Juventude e escolarização (1980/1998). Brasília, MEC/ INEP/Comped (Estado do Conhecimento, 7).

Sposito, M. P. \& Carrano, P. C. (2003), "Juventude e políticas públicas no Brasil". Revista Brasileira de Educação, 24: 16-39, set./dez., São Paulo, Anped/Autores Associados.

TCU - Tribunal de Contas da Uniao. (2004), Avaliação do TCU sobre o Projeto Agente Jovem. Brasília, TCU, Secretaria de Fiscalização e Avaliação de Governo, www.tcu.gov.br (avaliação de programas de governo).

Zaluar, Alba. (1997), "Exclusão e políticas públicas: dilemas teóricos e alternativas políticas". Revista Brasileira de Ciências Sociais, 12 (25), out.

ZiBAS, Dagmar et al. (2004), "A gestão escolar como cenário de inovação educativa: o protagonismo de alunos e pais no ensino médio". Relatório de Pesquisa, Departamento de Pesquisas Educacionais.

\section{Resumo}

A face oculta da transferência de renda para jovens no Brasil

A partir da análise mais ampla do caráter das recentes políticas públicas dirigidas a jovens no Brasil e das orientaçōes conflitivas inerentes a esse campo, o artigo discute os pressupostos contidos em três programas públicos implementados no país: o Projeto Agente Jovem, o Programa Serviço Civil Voluntário e o Programa Bolsa Trabalho Renda. Após uma caracterização geral de cada um deles, sem ignorar aspectos de sua diversidade, a análise concentra-se nos paradoxos e ambigüidades subjacentes a seu formato comum: a transferência de renda atrelada à exigência de algum tipo de contrapartida do público juvenil, em geral o retorno/permanência na escola e a realização de atividades de caráter socioeducativo ou comunitário. Sem negar o benefício promovido pelo acesso à renda, o artigo alerta para a possibilidade de disseminação de novas formas de dominação a partir da adoção desse modelo nas ações públicas dirigidas aos jovens.

Palavras-chave: Juventude; Políticas públicas; Programas socioeducativos; Transferência de renda. 


\section{Abstract}

The hidden face of the income transference for youths in Brazil

Based on a broader analysis of the character of recent public policies directed at youths in Brazil and on the conflicting orientations inherent in this field, this paper deals with the presuppositions contained in three public programs taking place in the country: the Young Agent Project, the Voluntary Civil Service Program and the WorkIncome Grant Program. To begin with, a general characterization of each of these programs is made, taking into consideration the aspects of their diversity; secondly, the analysis focuses on the paradoxes and ambiguities feature to their common underlining: the transference of income linked to some kind of repayment by the youngsters, usually the return to or the carrying on at school and the fulfillment of socioeducational or community type activities. Taking into account the beneficial side of access to income, this paper cautions the reader on the possibility of dissemination of new forms of domination based on the adoption of this model in public policies directed at youngsters.

Keywords: Youth; Public policies; Socio-educational programs; Income transference.

Texto recebido e aprovado em 20/10/2005.

Marilia Pontes Sposito é professora titular de Sociologia da Educação da Faculdade de Educação da USP. E-mail: sposito@usp.br.

Maria Carla Corrochano é mestre em Educação e cursa o doutorado em Educação na Faculdade de Educação da USP. Email: mcarla@usp.br.

172 Tempo Social, revista de sociologia da USP, v. 17, n. 2 